\title{
Can mesenchymal stem cells be used to treat COVID-19-induced pneumonia? (Review)
}

\author{
İDİL ÇETIN and MEHMET TOPÇUL \\ Department of Biology, Faculty of Science, Istanbul University, Istanbul 34459, Turkey
}

Received April 20, 2020; Accepted September 8, 2020

DOI: $10.3892 /$ br.2020.1369

\begin{abstract}
The novel severe acute respiratory syndromecoronavirus-2 (SARS-CoV-2) which has resulted in the COVID-19 pandemic, infection by which is commonly characterized by a sore throat, fever and cough, was first reported in Wuhan, China on 31st December 2019. This novel disease is mild in certain individuals, usually younger healthy individuals, whereas the elder and those with underlying health conditions develop severe symptoms and may die as a result of the disease or associated complications. Along with pneumonia, hypercytokinemia, also termed a cytokine storm, is one of the most common pathologies observed in patients with COVID-19. As patients react to the infection with the virus differently; in certain individuals, a cytokine storm may result in death. At present, there is no cure or widely available vaccine for the novel coronavirus. However, it has been hypothesized that mesenchymal stem cells may assist in the treatment/management of the cytokine storm due to their immunomodulating properties.
\end{abstract}

\section{Contents}

1. Introduction

2. COVID-19-induced pneumonia

3. Cytokine storm

4. MSCs

5. Conclusions

\section{Introduction}

The COVID-19 pandemic caused by the severe acute respiratory syndrome (SARS)-CoV-2 virus, which was first reported

Correspondence to: Dr İdil Çetin, Department of Biology, Faculty of Science, Istanbul University, Şehzadebaşı Cd., Vezneciler, Istanbul 34459, Turkey

E-mail: idil.cetin@istanbul.edu.tr

Key words: COVID 19, pneumonia, cytokine storm, mesenchymal stem cells on 31st of December in Wuhan, China, has quickly spread to 6 continents and hundreds of countries, and is the first pandemic caused by a coronavirus (CoV) (1).

$\mathrm{CoV}$ are a large family of viruses that can cause disease in humans and animals. They are RNA based viruses, exhibit positive polarity, and are enveloped and non-segmented, belonging to the Orthocoronavirinae subfamily (2). The total genome length of $\mathrm{CoV}$ is $\sim 30 \mathrm{~Kb}$. There are different regions in the genome, including a 5'-terminal noncoding region, an open reading box $1 \mathrm{a} / \mathrm{b}$-coding region, an $\mathrm{S}$ region encoding, a spike glycoprotein (S protein), an E region encoding the envelope protein (E protein), an $\mathrm{M}$ region encoding the membrane protein ( $\mathrm{M}$ protein), an $\mathrm{N}$ region encoding the nucleocapsid protein ( $\mathrm{N}$ protein) and a -3 '-terminal non-coding region (3). Genomic sequence analysis of COVID-19 shows $88 \%$ similarity with two bat-derived SARS-like coronaviruses, suggesting its origins in a species other than humans $(4,5)$.

COVID-19 may pass through mucous membranes, particularly the nasal and larynx mucosa, and then enters the lungs through the respiratory tract. SARS-CoV-2 requires the angiotensin-converting enzyme 2 (ACE2), similar to how SARS-CoV requires ACE-2 (6), as the virus appears to attack organs that express ACE2 (7-9). The first stage of pathogenesis of the virus is the identification ACE2 receptors by its spike protein. Thus, cells expressing ACE2 are likely the first cells to be infected (10). The ACE2 receptor is widely expressed on the surface of numerous types of human cells, particularly the alveolar type II cells of the lungs $(11,12)$. Other organs which express high quantities of ACE2 receptor are the heart, liver, kidneys and digestive organs. In fact, a common cause of spread of the virus within a host is that endothelial and smooth muscle cells in almost all organs express ACE2 receptors, and thus, the virus can enter the bloodstream with relative ease. Since any tissue or organ expressing ACE2 may serve as the battlefield between the novel coronavirus and immune cells, complications such as acute respiratory distress syndrome, acute myocardial damage, arrhythmia, acute kidney injury, shock and even death may be observed $(13,14)$. It has been reported that human-to-human transmission of SARS-CoV occurs via the binding between the receptor-binding domain of the virus spikes and cellular ACE2 receptors $(5,15)$.

The clinical spectrum of COVID-19 symptoms varies from asymptomatic or pauci-symptomatic forms to clinical conditions, characterized by respiratory failure requiring mechanical ventilation and support in intensive care units, to 
multiorgan and systemic manifestations such as sepsis, septic shock and multiple organ dysfunction syndrome $(16,17)$.

The aim of the present review is to discuss the role of mesenchymal stem cells (MSCs), which are known to possess regulatory functions on the immune system, as a means of alleviating or eliminating the more severe consequences of the cytokine storm along with pneumonia, two symptoms most commonly associated with death in infected patients.

\section{COVID-19-induced pneumonia}

Pneumonia refers to the filling of air vesicles in the lung with an inflammatory fluid. Viruses, bacteria and rarely even fungal infections cause pneumonia as a complication of infection. These pathogens begin to attack cells that form the lining of the lungs and inflame small sacs where gaseous exchange occurs. The breathing of a patient becomes shorter and harder, and as the cells die, the lungs become filled with fluids and debris further reducing breathing capacity, and secondary infections can develop as a result. This condition is called pneumonia. In severe cases, the patient requires a respirator to assist their breathing, although the ventilator may not prove effective in some individuals, and this is dependent on the specific reaction of a patient's immune system. That is, the response mounted by the immune system will dictate a patient's outcome. The immune system of critically ill patients becomes overly activated, a condition called cytokine storm, where a large number of white blood cells are activated and release inflammatory cytokines that further activate more white blood cells $(18,19)$.

Pneumonia appears to be the most common severe manifestation of COVID-19, distinguished primarily by fever, dry cough, dyspnoea and bilateral infiltrates on chest imaging (18). Models to predict outcomes of patients infected with COVID-19 take into account three factors: i) The severity of the infection, host response, physiological reserve and comorbidities; ii) the ventilatory responsiveness of the patient to hypoxemia and the time elapsed between the onset of the disease; and iii) the unique observations/manifestations in patients and the capacity of individual hospitals to manage patients. The balance between these factors leads to the development of a time-related disease spectrum with two primary phenotypes. Type $\mathrm{L}$ is characterized by low elastance, low ventilation-to-perfusion ratio, low lung weight and a low capacity to recruit immune system actors. Type $\mathrm{H}$ is characterized by high elastance, high right-to-left shunt, high lung weight and high a high capacity to recruit immune system actors (19-22).

\section{Cytokine storm}

Cytokine storm syndrome refers to a range conditions which ultimately manifests as systemic inflammation, multi-organ failure, hyperferritinemia and, if untreated, often death (23). Numerous pathogenic viruses and bacteria have been found to induce cytokine storms or hypercytokinemia (24-26). These pathogens disrupt the balance between a physiological and pathophysiological inflammatory response, pushing from being beneficial to destructive via positive feedback in immune cells and upregulation of proinflammatory markers, in particular cytokines such as TNF- $\alpha$, IL-1 $\beta$, IL- 8 and IL-6. This results in symptoms such as hypotension, fever and oedema, and may eventually result in organ dysfunction and death (27).

Pathogen-induced lung injury can progress to acute lung injury or its more severe form, acute respiratory distress syndrome (ARDS), as observed with patients infected with SARS-CoV or influenza viruses (28). A hallmark of SARS-CoV-2 pathogenesis is the presence of a cytokine storm in the lungs (29). One of the primary mechanisms underlying development of ARDS is the cytokine storm, a deadly uncontrolled systemic inflammatory response resulting from the release of large amounts of pro-inflammatory cytokines (IFN- $\alpha$, IFN- $\gamma$, IL-1 $\beta$, IL-6, IL-12, IL-18, IL-33, TNF- $\alpha$ and TGF- $\beta$, amongst others) and chemokines (CCL2, CCL3, CCL5, CXCL8, CXCL9 and CXCL10, amongst others) by immune effector cells in response to SARS-CoV infection (14,30-32). The cytokine storm initiates a violent attack by the immune system on the host body, resulting in ARDS and multiple organ failure and ultimately death in severe cases of SARS-CoV-2 infection, similar to that observed in patients who were infected with SARS-CoV and MERS-CoV (33). IL-1 $\beta$ is a key cytokine driving proinflammatory activity in bronchoalveolar lavage fluid of patients with lung injury (28). Pathophysiological levels of inflammation in the lungs also can have other systemic effects on other organs (34).

\section{MSCs}

The self-renewal and differential capacity of stem cells as potential tools for regeneration, restoration or replacement therapies in a variety of disease conditions has been described previously (35). MSCs are a heterogeneous population of cells with the potential to differentiate into a range of somatic lineages, and were originally described as adherent cells with a fibroblast-like appearance capable of differentiating into osteocytes, chondrocytes, adipocytes, tenocytes and myocytes (36-38). MSCs also support haematopoiesis, possess immunomodulatory properties and specifically migrate to damaged sites. MSC migration is mediated by growth factors, chemokines, adhesion molecules and toll-like receptors (39). MSCs have been successfully used to reverse graft-versus-host disease in patients receiving bone marrow transplants $(40,41)$, particularly in patients diagnosed with severe steroid resistance (42-44). Similarly, in patients with systemic lupus erythematosus and Crohn's disease, both autologous and allogeneic MSCs are able to suppress inflammation and reduce damage to the kidneys and bowel, possibly through the induction of regulatory T cells (45-48).

Immunomodulatory role of MSCs. Following COVID-19 infection-mediated initiation of immune overreaction in the body, the immune system produces large quantities of inflammatory factors, causing a cytokine storm, including an overproduction of immune cells and cytokines (49). At present, there are no specific antiviral treatments recommended for treatment of COVID-19, and no vaccines are currently widely available. Antibacterial agents are ineffective due to the viral nature of the infection. Thus, therapeutic strategies are limited to palliative care and assisted ventilation for patients with severe pneumonia (50).

MSCs are considered a promising tool for cell therapy, in particular for management of inflammatory diseases, based 


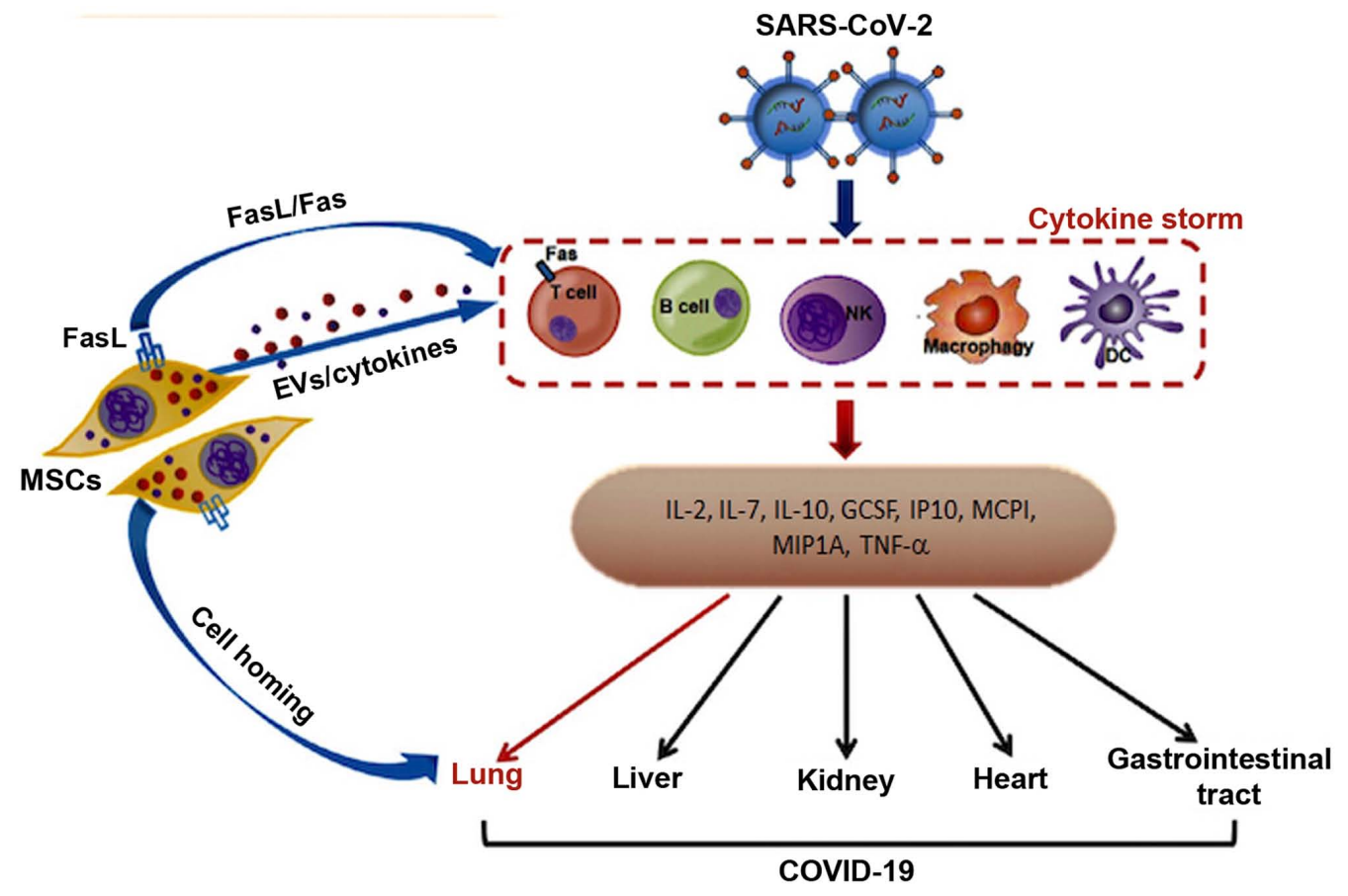

Figure 1. Potential mechanism by which MSCs may manage the severe symptoms of COVID-19 (71). MSC, mesenchymal stem cell; EV, extracellular vesicles; NK, natural killer; DC, dendritic cell.

on their immunomodulatory properties and paracrine effects through trophic factors with anti-fibrotic, anti-apoptotic or pro-angiogenic properties $(51,52)$. MSCs regulate the function of a broad range of immune cells (52-59) and are activated by inflammatory mediators released from activated immune cells (such as IFN- $\gamma$, IL-1 $\beta$ and TNF- $\alpha$ ) $(60,61)$.

Studies have suggested that MSCs may exhibit immunosuppressive or immunomodulatory properties $(53,61,62-65)$. MSCs are hypothesized to possess the ability to reduce inflammatory effects and defend against a cytokine storm (66). MSCs home in on the injured site due to the presence of local cytokine storm, produced by secretion of activated immune cells. Activation and migration of MSCs results in secretion of multiple immunomodulatory and growth factors. Depending on the cytokine signal (acute vs. chronic inflammation), MSCs initiate the immunoregulatory response and repair the injured site, or are unable to inhibit the persisting chronic inflammatory signals being generated as a result of cellular fibrosis (67).

Alleviation of acute respiratory disease and reversal of pulmonary fibrosis in SARS-CoV-2-infected patients is mediated by three curative properties of MSCs: i) Directly inducing the apoptosis of activated $\mathrm{T}$ cells to relieve the aberrant and excessive immune responses; ii) homing toward specific sites of injury in the lung to maintain homeostasis as well as promote regeneration; and iii) releasing cytokines to diminish the inflammatory response and release of extracellular vesicles to stimulate tissue repair (Fig. 1) (68). Notably, it has been shown that cytokines released by MSCs may potently inhibit neutrophil intravasation and enhance the differentiation of macrophages $(69,70)$.

Due to a lack of expression of co-stimulatory molecules and HLA-II, MSCs are regarded as non-immunogenic cells, thus transplantation into an allogeneic host may not require the use of immunosuppressive treatments $(71,72)$. Moreover, MSCs possess immunomodulatory properties and can suppress and inhibit the activation, maturation and proliferation of innate and adaptive immune cells (B cells, T cells, NK cells, dendritic cells and macrophages) (73).

Following intravenous injection of MSCs (systemic infusion), a proportion of the injected cells are trapped in the lung, and this is normally considered a limitation of currently used administration methods. However, with regard to treatment of COVID-19 infection, this may prove beneficial, as these trapped MSCs may promote repair of the pulmonary microenvironment, protect alveolar epithelial cell regeneration, intercept pulmonary fibrosis and reduce lung dysfunction resulting from the COVID-19 infection and pneumonia (13).

Umbilical cord cells, umbilical cord blood, Wharton's jelly, menstrual blood, dental pulp and commercially produced-MSCs are important sources of MSCs that should be assessed in clinical trials as potential treatment of patients infected with COVID-19. However, the process of developing novel therapeutic strategies and introducing them in a clinical setting may result in identification of important practical implications/complications which may not have taken into consideration beforehand (74).

\section{Conclusions}

Due to the novel coronavirus, $>27$ million individuals have been infected and almost 900,000 deaths COVID-19-realted deaths have been reported (correct as of 8 th of September, 2020). Whilst certain patients infected with COVID-19 do not shown symptoms, predominantly younger healthy individuals, a range of symptoms have been reported, which vary from those with mild complaints (mild fever, cough and, transient loss of taste or smell, amongst others) to more severe symptoms which require admittance to intensive 
care and assisted mechanical ventilation. The absence of a definitive treatment for management of the disease and the absence of a vaccine imposes limitations on the management of the spread of the disease, and thus has required governmental bodies to rely on more rudimentary measures, such as social distancing and lockdowns of certain regions to reduce the spread. In addition, the unique immune systems of patients react differently, and the extent of the cytokine storm produced by an individuals may result in death if excessive. It is hypothesized that the use of mesenchymal stem cells for their immunomodulatory properties may result in improved patient outcomes. As mesenchymal stem cells are pluripotent stromal stem cells, they may be successful in treatment and management of COVID-19 infection due to their immune regulatory properties, and thus may be useful for treating patients who develop more severe symptoms. However, additional studies, including clinical trials and meta-analyses are required before widescale adoption in a clinical setting.

\section{Acknowledgements}

Not applicable.

\section{Funding}

This review was supported by funding from the Scientific Research Project Coordination Unit of Istanbul University (grant no. FBA-2017-24288).

\section{Availability of data and materials}

Not applicable.

\section{Authors' contributions}

IC and MT both wrote and revised the article. Both authors read and approved the final manuscript.

\section{Ethics approval and consent to participate}

Not applicable.

\section{Patient consent for publication}

Not applicable.

\section{Competing interests}

The authors declare that they have no competing interests.

\section{References}

1. Uğraş Dikmen A, Kına HM, Özkan S and İlhan MN Epidemiology of COVID-19: What we learn from pandemic. J Biotechnol and Strategic Health Res 1: 29-36, 2020.

2. Zhu N, Zhang D, Wang W, Li X, Yang B, Song J, Zhao X, Huang B, Shi W, Lu R, et al: A novel coronavirus from patients with pneumonia in China, 2019. N Engl J Med 382: 727-33, 2020.

3. Zumla A, Chan JFW, Azhar EI, Hui DS and Yuen KY: Coronaviruses-drug discovery and therapeutic options. Nat Rev Drug Discov 15: 327-347, 2016.
4. Lu R, Zhao X, Li J, Niu P, Yang B, Wu H, Wang W, Song H, Huang B, Zhu N, et al: Genomic characterisation and epidemiology of 2019 novel coronavirus: Implications for virus origins and receptor binding. Lancet 395: 565-574, 2020.

5. Wan Y, Shang J, Graham R, Baric RS and Li F: Receptor recognition by novel coronavirus from Wuhan: An analysis based on decade-long structural studies of SARS. J Virol 94: e00127-20, 2020.

6. Zhou P, Yang XL, Wang XG, Hu B, Zhang L, Zhang W, Si HR, Zhu Y, Li B, Huang CL, et al: A pneumonia outbreak associated with a new coronavirus of probable bat origin. Nature 579: 270-273, 2020.

7. Rose-John S: Interleukin-6 family cytokines. Cold Spring Harb Perspect Biol 10: a028415, 2018.

8. Chen J, Hu C, Che L, Tang L, Zhu Y, Xu X, Chen L, Gao H, Lu X, Yu L, et al: Clinical study of mesenchymal stem cell treatment for acute respiratory distress syndrome induced by epidemic influenza A (H7N9) infection: A hint for COVID-19 treatment. Engineering (Beijing): Feb 28, 2020 (Epub ahead of print).

9. Bennardo F, Buffone $C$ and Giudice A: New therapeutic opportunities for COVID-19 patients with Tocilizumab: Possible correlation of interleukin- 6 receptor inhibitors with osteonecrosis of the jaws. Oral Oncol 106: 104659, 2020.

10. Rothan HA and Byrareddy SN: The epidemiology and pathogenesis of coronavirus disease (COVID-19) outbreak. J Autoimmun 109: 102433, 2020.

11. Hamming I, Timens W, Bulthuis ML, Lely AT, Navis G and van Goor H: Tissue distribution of ACE2 protein, the functional receptor for SARS coronavirus. A first step in understanding SARS pathogenesis. J Pathol 203: 631-637, 2004.

12. Vergano M, Bertolini G, Giannini A, Giuseppe G, Livigni S, Mistraletti G and Petrini F: Raccomandazioni di etica clinica per l'ammissione a trattamenti intensivi e per la loro sospensione, in condizioni eccezionali di squilibrio tra necessità e risorse disponibili. versione 01. SIAARTI, 2020. https://www.siaarti.it/ SiteAssets/News/COVID19\%20-\%20documenti\%20SIAARTI/ SIAARTI\%20-\%20 Covid19\%20-\%20Raccomandazioni $\% 20$ di\%20etica\%20clinica.pdf. Accessed March 6, 2020.

13. Leng Z, Zhu R, Hou W, Feng Y, Yang Y, Han Q, Shan G, Meng F, Du D, Wang S, et al: Transplantation of ACE2 mesenchymal stem cells improves the outcomes of patients with COVID-19 pneumonia. Aging Dis 11: 216-228, 2020.

14. Huang C, Wang Y, Li X, Ren L, Zhao J, Hu Y, Zhang L, Fan G, $\mathrm{Xu} \mathrm{J}, \mathrm{Gu} \mathrm{X}$, et al: Clinical features of patients infected with 2019 novel coronavirus in Wuhan, China. Lancet 395: 497-506, 2020.

15. Jaimes JA, Millet JK, Stout AE, Andre NM and Whittaker GR: A tale of two viruses: The distinct spike glycoproteins of feline coronaviruses. Viruses 12: 83, 2020.

16. Wu Z and Mc Googan JM: Characteristics of and important lessons from the coronavirus disease 2019 (COVID-19) outbreak in China: Summary of a report of 72314 cases from the Chinese center for disease control and prevention. JAMA 323: 1239-1242, 2020.

17. Del Rio C and Malani PN: 2019 novel coronavirus-important information for clinicians. JAMA 323: 1039-1040, 2020.

18. World Health Organization (WHO): WHO Director-General's opening remarks at the media briefing on COVID-19-24 February 2020. https://www.who.int/dg/speeches/detail/who-director-ge neral-s-op-ening-remarks-at-themedia-briefing-on-covid-19-24-february-2020. Accessed February 26, 2020.

19. Gattinoni L, Pesenti A, Avalli L, Rossi F and Bombino M: Pressure-volume curve of total respiratory system in acute respiratory failure. Computed tomographic scan study. Am Rev Respir Dis 136: 730-736, 1987.

20. Gattinoni L, Caironi P, Cressoni M, Chiumello D, Ranieri VM, Quintel M, Russo S, Patroniti N, Cornejo R and Bugedo G: Lung recruitment in patients with the acute respiratory distress syndrome. N Engl J Med 354: 1775-1786, 2006.

21. Maiolo G, Collino F, Vasques F, Rapetti F, Tonetti T, Romitti F, Cressoni M, Chiumello D, Moerer O, Herrmann P, et al: Reclassifying acute respiratory distress syndrome. Am J Respir Crit Care Med 197: 1586-1595, 2018.

22. Gattinoni L, Chiumello D, Caironi P, Busana M, Romitti F, Brazzi L and Camporota L: COVID-19 pneumonia: Different respiratory treatments for different phenotypes? Intensive Care Med 46: 1099-1102, 2020.

23. Behrens EM and Koretzky GA: Review: Cytokine storm syndrome: Looking toward the precision medicine era. Arthritis Rheumatol 69: 1135-1143, 2017. 
24. Us D: Cytokine storm in avian influenza. Mikrobiyol Bul 42: 365-380, 2008 (In Turkish)

25. Mares CA, Ojeda SS, Morris EG, Li Q and Teale JM: Initial delay in the immune response to Francisella tularensis is followed by hypercytokinemia characteristic of severe sepsis and correlating with upregulation and release of damage-associated molecular patterns. Infect Immun 76: 3001-3010, 2008.

26. de Castro IF, Guzmán-Fulgencio M, García-Alvarezand M and Resino S: First evidence of a pro-inflammatory response to severe infection with influenza virus H1N1. Crit Care 14: 115, 2010.

27. Tisoncik JR, Korth MJ, Simmons CP, Farrar J, Martin TR and Katze MG: Into the eye of the cytokine storm. Microbiol Mol Biol Rev 76: 16-32, 2012.

28. Pugin J, Ricou B, Steinberg KP, Suter PM and Martin TR: Proinflammatory activity in bronchoalveolar lavage fluids from patients with ARDS, a prominent role for interleukin-1. Am J Respir Crit Care Med 153: 1850-1856, 1996.

29. Metcalfe SM: Mesenchymal stem cells and management of COVID-19 pneumonia. Med Drug Discov 5: 1000192, 2020.

30. Williams AE and Chambers RC: The mercurial nature of neutrophils: Still an enigma in ARDS? Am J Physiol Lung Cell Mol Physiol 306: L217-L230, 2014.

31. Channappanavar R and Perlman S: Pathogenic human coronavirus infections: Causes and consequences of cytokine storm and immunopathology. Semin Immunopathol 39: 529-539, 2017

32. Cameron MJ, Bermejo-Martin JF, Danesh A, Muller MP and Kelvin DJ: Human immunopathogenesis of severe acute respiratory syndrome (SARS). Virus Res 133: 13-19, 2008.

33. Xu Z, Shi L, Wang Y, Zhang J, Huang L, Zhang C, Liu S, Zhao P, Liu H, Zhu L, et al: Pathological findings of COVID-19 associated with acute espiratory distress syndrome. Lancet Resp Med 8: 420-422, 2020.

34. Imai Y, Parodo J, Kajikawa O, de Perrot M, Fischer S, Edwards V, Cutz E, Liu M, Keshavjee S, Martin TR, et al: Injurious mechanical ventilation and end-organ epithelial cell apoptosis and organ dysfunction in an experimental model of acute respiratory distress syndrome. JAMA 289: 2104-2112, 2003

35. Kögler G, Sensken S, Airey JA, Trapp T, Müschen M, Feldhahn N, Liedtke S, Sorg RV, Fischer J, Rosenbaum C, et al: A new human somatic stem cell from placental cord blood with intrinsic pluripotent differentiation potential. J Exp Med 200: 123-135, 2004.

36. Deng ZL, Sharff KA, Tang N, Song WX, Luo J, Luo X, Chen J, Bennett E, Reid R, Manning D, et al: Regulation of osteogenic differentiation during skeletal development. Front Biosci 13: 2001-2021, 2008.

37. Friedenstein AJ, Petrakova KV, Kurolesova AI and Frolova GP Heterotopic of bone marrow. Analysis of precursor cells for osteogenic and hematopoietic tissues. Transplantation 6: 230-247, 1968

38. Luu HH, Song WX, Luo X, Manning D, Luo J, Deng ZL, Sharff KA, Montag AG, Haydon RC and He TC: Distinct roles of bone morphogenetic proteins in osteogenic differentiation of mesenchymal stem cells. J Orthop Res 25: 665-677, 2007.

39. Entschladen F and Zänker KS (eds): Cell migration: Signalling and mechanisms. Karger, Basel, pp1-6, 2010.

40. Müller I, Kordowich S, Holzwarth C, Isensee G, Lang P, Neunhoeffer F, Dominici M, Greil J and Handgretinger R: Application of multipotent mesenchymal stromal cells in pediatric patients following allogeneic stem cell transplantation. Blood Cells Mol Dis 40: 25-32, 2008

41. Prasad VK, Lucas KG, Kleiner GI, Talano JA, Jacobsohn D, Broadwater G, Monroy R and Kurtzberg J: Efficacy and safety of ex vivo cultured adult human mesenchymal stem cells (Prochymal ${ }^{\mathrm{TM}}$ ) in pediatric patients with severe refractory acute graft-versus-host disease in a compassionate use study. Biol Blood Marrow Transplant 17: 534-541, 2011.

42. Kebriaei P, Isola L, Bahceci E, Holland K, Rowley S, McGuirk J, Devetten M, Jansen J, Herzig R, Schuster M, et al: Adult human mesenchymal stem cells added to corticosteroid therapy for the treatment of acute graft-versus-host disease. Biol Blood Marrow Transplant 15: 804-811, 2009.

43. Wu KH, Chan CK, Tsai C, Chang YH, Sieber M, Chiu TH, Ho M, Peng CT, Wu HP and Huang JL: Effective treatment of severe steroid-resistant acute graft-versus- host disease with umbilical cord-derived mesenchymal stem cells. Transplantation 91: 1412-1416, 2011

44. Le Blanc K, Frassoni F, Ball L, Locatelli F, Roelofs H, Lewis I, Lanino E, Sundberg B, Bernardo ME, Remberger M, et al: Mesenchymal stem cells for treatment of steroid-resistant, severe, acute graft-versus-host disease: A phase II study. Lancet 371: 1579-1586, 2008.
45. Sun L, Wang D, Liang J, Zhang H, Feng X, Wang H, Hua B, Liu B, Ye S, Hu X, et al: Umbilical cord mesenchymal stem cell transplantation in severe and refractory systemic lupus erythematosus. Arthritis Rheum 62: 2467-2475, 2010.

46. Carrion F, Nova E, Ruiz C, Diaz F, Inostroza C, Rojo D, Mönckeberg G and Figueroa FE: Autologous mesenchymal stem cell treatment increased $\mathrm{T}$ regulatory cells with no effect on disease activity in two systemic lupus erythematosus patients. Lupus 19: 317-322, 2010.

47. Ciccocioppo R, Bernardo ME, Sgarella A, Maccario R, Avanzini MA, Ubezio C, Minelli A, Alvisi C, Vanoli A, Calliada F, et al: Autologous bone marrow-derived mesenchymal stromal cells in the treatment of fistulising Crohn's disease. Gut 60: 788-798, 2011.

48. Duijvestein M, Vos AC, Roelofs H, Wildenberg ME, Wendrich BB, Verspaget HW, Kooy-Winkelaar EM, Koning F, Zwaginga JJ, Fidder $\mathrm{HH}$, et al: Autologous bone marrow-derived mesenchymal stromal cell treatment for refractory luminal Crohn's disease: Results of a phase I study. Gut 59: 1662-1669, 2010

49. Mehta P, Mcauley DF, Brown M, Sanchez E, Tattersall RS, Manson JJ; HLH Across Speciality Collaboration, UK: Correspondence COVID-19: Consider cytokine storm syndromes and immunosuppression. Lancet 395: 1033-1034, 2020.

50. Bari E, Ferrarotti I, Saracino L, Perteghella S, Torre ML and Corsico AG: Mesenchymal stromal cell secretome for severe COVID-19 infections: Premises for the therapeutic use. Cells 9: 924, 2020.

51. Singer NG and Caplan AI: Mesenchymal stem cells: Mechanisms of inflammation. Annu Rev Pathol 6: 457-478, 2011.

52. Bernardo ME and Fibbe WE: Mesenchymal stromal cells: Sensors and switchers of inflammation. Cell Stem Cell 13: 392-402, 2013.

53. Di Nicola M, Carlo-Stella C, Magni M, Milanesi M, Longoni PD, Matteucci P, Grisanti S and Gianni AM: Human bone marrow stromal cells suppress t-lymphocyte proliferation induced by cellular or non- specific mitogenic stimuli. Blood 99: 3838-3843, 2002.

54. Krampera M, Glennie S, Dyson J, Scott D, Laylor R, Simpson E and Dazzi F: Bone marrow mesenchymal stem cells inhibit the response of naive and memory antigen-specific $\mathrm{T}$ cells to their cognate peptide. Blood 101: 3722-3729, 2003

55. Ghannam S, Pène J, Moquet-Torcy G, Jorgensen $\mathrm{C}$ and Yssel $\mathrm{H}$ Mesenchymal stem cells inhibit human Th17 cell differentiation and function and induce a $\mathrm{T}$ regulatory cell phenotype. J Immunol 185: 302-312, 2010.

56. Prigione I, Benvenuto F, Bocca P, Battistini L, Uccelli A and Pistoia V: Reciprocal interactions between human mesenchymal stem cells and gammadelta $\mathrm{T}$ cells or invariant natural killer T cells. Stem Cells 27: 693-702, 2009.

57. Corcione A, Benvenuto F, Ferretti E, Giunti D, Cappiello V, Cazzanti F, Risso M, Gualandi F, Mancardi GL, Pistoia V and Uccelli A: Human mesenchymal stem cells modulate B-cell functions. Blood 107: 367-372, 2006.

58. Raffaghello L, Bianchi G, Bertolotto M, Montecucco F, Busca A, Dallegri F, Ottonello L and Pistoia V: Human mesenchymal stem cells inhibit neutrophil apoptosis: A model for neutrophil preservation in the bone marrow niche. Stem Cells 26: 151-162, 2008.

59. DelaRosa O, Sánchez-Correa B, Morgado S, Ramírez C, del Río B, Menta R, Lombardo E, Tarazona R and Casado JG: Human adipose-derived stem cells impair natural killer cell function and exhibit low susceptibility to natural killer-mediated lysis. Stem Cells Dev 21: 1333-1343, 2012.

60. Krampera M, Cosmi L, Angeli R, Pasini A, Liotta F, Andreini A Santarlasci V, Mazzinghi B, Pizzolo G, Vinante F, et al: Role for interferon-gamma in the immunomodulatory activity of human bone marrow mesenchymal stem cells. Stem Cells 24: 386-398, 2006.

61. Prasanna SJ, Gopalakrishnan D, Shankar SR and Vasandan AB: Proinflammatory cytokines, IFNgamma and TNFalpha, influence immune properties of human bone marrow and Wharton jelly mesenchymal stem cells differentially. PLoS One 5: e9016, 2010.

62. Frank MH and Sayegh MH: Immunomodulatory functions of mesenchymal stem cells. Lancet 363: 1411-1412, 2004.

63. Horwitz EM, Gordon PL, Koo WK, Marx JC, Neel MD, McNall RY, Muul L and Hofmann T: Isolated allogeneic bone marrow-derived mesenchymal cells engraft and stimulate growth in children with osteogenesis imperfecta: Implications for cell therapy of bone. Proc Natl Acad Sci USA 99. 8932-8937, 2002.

64. Koç ON, Day J, Nieder M, Gerson SL, Lazarus HM and Krivit W: Allogeneic mesenchymal stem cell infusion for treatment of meta-chromatic leukodystrophy (MLD) and hurler syndrome (MPS-IH). Bone Marrow Transplant 30: 215-222, 2002. 
65. Le Blanc K: Immunomodulatory effects of fetal and adult mesenchymal stem cells. Cytotherapy 5: 485-489, 2003.

66. Chen C, Zhang XR, Ju ZY and He WF: Advances in the research of mechanism and related immunotherapy on the cytokine storm induced by coronavirus disease 2019. Zhonghua Shao Shang Za Zhi 36: 471-475, 2020 (In Chinese).

67. Rawat S, Gupta S and Mohanty S: Mesenchymal stem cells modulate the immune system in developing therapeutic interventions 2019.

68. Abraham A and Krasnodembskaya A: Mesenchymal stem cell-derived extracellular vesicles for the treatment of acute respiratory distress syndrome. Stem Cells Transl Med 9: 28-38, 2020.

69. Xu AL, Rodriguez LA II, Walker KP III, Mohammadipoor A, Kamucheka RM, Cancio LC, Batchinsky AI and Antebi B: Mesenchymal stem cells reconditioned in their own serum exhibit augmented therapeutic properties in the setting of acute respiratory distress syndrome. Stem Cells Transl Med 8: 1092-1106, 2019.
70. Morrison TJ, Jackson MV, Cunningham EK, Kissenpfennig A, McAuley DF, O'Kane CM and Krasnodembskaya AD: Mesenchymal stromal cells modulate macrophages in clinically relevant lung injury models by extracellular vesicle mitochondrial transfer. Am J Respir Crit Care Med 196: 1275-1286, 2017.

71. Ji F, Li L, Li Z, Jin Y and Liu W: Mesenchymal stem cells as a potential treatment for critically ill patients with coronavirus disease 2019. Stem Cells Transl Med 9: 813-814, 2020.

72. Noël D, Djouad F, Bouffi C, Mrugala D and Jorgensen C: Multipotent mesenchymal stromal cells and immune tolerance. Leuk Lymphoma 48: 1283-1289, 2007.

73. Chen X, Armstrong MA and Li G: Mesenchymal stem cells in immunoregulation. Immunol Cell Biol 84: 413-421, 2006.

74. Golchin A, Seyedjafari E and Ardeshirylajimi A: Mesenchymal stem cell therapy for COVID-19: Present or future. Stem Cell Rev Rep 16: 427-433, 2020. 